\title{
ANALYSIS OF PUBLIC PERCEPTION AND INTEREST IN THE DECISION TO CHOOSE ACCOUNTING MAJOR
}

\author{
Hendi Prihanto*), Watriningsih \\ Prof. Dr. Moestopo (Beragama) University \\ hp_torana@yahoo.com
}

\begin{abstract}
This study aims to find out the influence of public perception and interest on the decision to choose accounting major. The population of the study is high schools in Kebayoran Baru. The data is collected using clusters in South Jakarta. The data is obtained by distributing questionnaires to the students in twelfth grade who will continue their study to higher education. This study applies quantitative method with causal relationship to determine the influence of the independent variables (perception and interest) on the dependent variable (public decision to choose accounting department). Research findings show that the perception and interest partially influence the decision to choose in positive and significant manner.
\end{abstract}

Keywords: Perception, Interest, Decision to Choose, Accounting.

\begin{abstract}
Abstrak
Penelitian ini bertujuan untuk mengetahui pengaruh persepsi dan minat masyarakat terhadap keputusan memilih jurusan akuntansi. Populasi penelitian adalah sekolah menengah di Kebayoran Baru. Data dikumpulkan menggunakan klaster di Jakarta Selatan. Data diperoleh dengan menyebarkan kuesioner kepada siswa di kelas dua belas yang akan melanjutkan studi ke pendidikan tinggi. Penelitian ini menggunakan metode kuantitatif dengan hubungan kausal untuk mengetahui pengaruh variabel independen (persepsi dan minat) terhadap variabel dependen (keputusan publik untuk memilih departemen akuntansi). Temuan penelitian menunjukkan bahwa persepsi dan minat secara parsial mempengaruhi keputusan untuk memilih secara positif dan signifikan.
\end{abstract}

Kata Kunci: Persepsi, Bunga, Keputusan Memilih, Akuntansi. 


\section{INTRODUCTION}

Accounting was born in Italy and Pacioli is the originator; although Babylon and Egypt has already known and practiced simple accounting for the use of money before that. In this modern era, accounting has undergone many rapid transformations and developments so that it is divided into several sub-sections according to the interests of organizations and individuals.

The development of the variety of accounting makes accounting grows rapidly as an independent and more innovative field. Therefore, there is a wide range of accounting such as financial accounting, management accounting, public sector accounting, tax accounting, Islamic accounting, information systems and others. The research findings show that average people choose accounting major because of their primary desire to be professionals in the field of accounting such as accountants, auditors, and consultants, followed by academic professions such as lecturers and teachers. Meanwhile, there is another assumption that future labor market is motivated by the assumption that the accountant will be required by many organizations and companies, particularly in Indonesia. However, many people view accounting as a complex, complicated, and difficult field. Therefore, it is not uncommon that many people think to avoid accounting and not pursue a degree in accounting and certification of accounting profession.

From the progress of accounting in education, it can be concluded that the disciplines required for an accountant consist of general knowledge, knowledge of management or organization, business, accounting, and taxation. The process of teaching and learning in higher education studying accounting should be able to transform learners to be more qualified graduates of science and moral.

\section{Data on the number of accounting graduates in Indonesia} year $2006-2010$

\begin{tabular}{|l|c|}
\hline \multicolumn{1}{|c|}{ Year } & Accounting Graduates \\
\hline 2010 & 35.304 people \\
\hline 2009 & 24.402 people \\
\hline 2008 & 25.649 people \\
\hline 2007 & 27.335 people \\
\hline 2006 & 28.988 people \\
\hline
\end{tabular}

Source : http://www.neraca.co.id

Data on the number of accountants in the region of Southeast Asia (ASEAN) in 2012

\begin{tabular}{|l|l|}
\hline \multicolumn{1}{|c|}{ Countries } & \multicolumn{1}{c|}{ Number of } \\
\hline Indonesia & 1.000 people \\
\hline Thailand & 6.000 people \\
\hline Malaysia & 2.500 people \\
\hline Filipina & 6.000 people \\
\hline
\end{tabular}

Source : PPAJP (Pusat Pembinaan Akuntan dan Jasa Penilai) 
Based on the existing phenomena and observations by some survey organizations, Indonesian accountants are far fewer in number than the ASEAN countries such as Malay, Singapore, and the Philippines. Thus, Indonesia encounters a crisis of accounting professions. The issue is addressed by performing CPA certification exam, held by IAPI (Indonesian Institute of Certified Public Accountants), as well as other educational institutions attended by many participants from all over Indonesia. Based on aforementioned problems, this study aims:

1) To prove the influence of public perception on decision to choose accounting major.

2) To prove the influence of public interest on decision to choose accounting major.

This study is expected to be helpful for academicians, to give contribution to information and literature of educational institutions, to give reference to examine similar variables for other researches, to be learned for the advancement of education, to provide information on public interests on education and to develop accounting professions in Indonesia.

\section{LITERATURE REVIEW}

\subsection{Perception}

Matlin in Novius (2008) defines perception as a process that involves prior insights in obtaining and interpreting the stimulus indicated by the senses. Perception is also a combination of external factors (visual stimulus) and internal factors (prior knowledge). Perception has two aspects, namely: pattern recognition and attention. Pattern recognition includes identification of a series of complex stimuli, influenced by the encountered context and past experiences.

Meanwhile, attention is the concentration of mental activity that involves further processing on a stimulus and at the same time does not move other stimuli. Rachmat (1993) states that perception is an experience of objects, events, or relationships obtained by concluding information and interpreting messages determined by personal and situational factors.

Another opinion expressed by Ikhsan (2010) states that the perception is how people see or interpret the events, objects, and people. People act on the basis of their perception regardless of whether this perception reflects the reality of the situation. In fact, everyone has their own perception of an event. The description of reality by someone may be far different from the description of reality by others.

Furthermore, Ikhsan explains that perception is a process that involves prior insights in obtaining and interpreting the stimulus indicated by the five senses. In other word, perception is also a combination of external factors (visual stimulus) and internal factors (prior knowledge). 


\subsection{Interest}

Interest is one aspect of personality playing a role in making future decisions. Furthermore, interest is a mental device that consists of a mixture of feelings, hope, conviction, prejudice, fear, or other tendencies that direct a person to a particular choice as proposed by Mappiare in Ginting (2005).

According to Sandjaja (2006), interest is a tendency that causes a person to look for or try activities in a specific field. Interest is also interpreted as a positive attitude towards environmental aspects. In addition, interest is also a permanent tendency to notice and enjoy an activity accompanied by joy. Furthermore, according to Crow and Crow in Gunarto (2007), there are some things related to interest that should be considered, namely:

1) The factor of inner urge

It is the stimulus coming from the environment/scope in accordance with the wishes/needs of someone to have an interest. One example is a tendency to learn. A person with a tendency to learn has a desire to gain knowledge.

2) The factor of social motive

An interest in an object/thing is influenced by internal as well as social motives. For example, someone put an interest to achieve highest achievements in order to achieve higher social status as well.

3) Emotional factor

Feeling and emotion affect subjects such as: a successful trip of someone in a particular event can evoke joyful feeling and add spirit and interest in the activity.

\subsection{Decision}

Discussion about decision cannot be separated from the theory of consumer behavior, since consumer behavior reflects the consumer's decision. Schiffman and Kanuk (2012) state that consumer behavior is the behavior of the consumers in searching, purchasing, using, evaluating, and ignoring products, services, or ideas expected to satisfy their needs by consuming the products or services offered.

Kotler and Keller (2012) state that consumer behavior is a study of how individuals, groups, and organizations select, purchase, and use the goods, services, ideas, or experiences to satisfy their needs and desires. Based on the aforementioned opinions, it can be concluded that the behavior by consumers of educational services is the activities of individuals who are directly involved in obtaining and using the services of education, including the decision-making process. According to Spanbauer (in Hidayah, 2007), external primary customers in a school are students who attend classes and use the services of the school. Therefore, it can be concluded that other external consumers are those who are close to the students, such as parents, family, and the parties employing graduate students and taxpayers who contribute to fund the school. Besides external customers, schools have internal customers such as their instructors, teacher aides, support staff, technical staff and managers Kotler and Keller, (2012). Consumer behavior will determine the decision-making process in their purchases. The decision-making process is a problem-solving approach that consists of five 
phases as follows:

1) Identification of the problem of purchasing process, starting when the buyer identifies a problem or a need.

2) Search for information about the consumer. A need will encourage a customer to search for much information about a needed product or service.

3) Alternative evaluation of some evaluation processes of consumers' decision. The latest models consider evaluation process of consumer as a cognitive process.

4) The decision to purchase is the process of real purchase.

5) The behavior after purchase.

\subsection{Accounting}

Accounting Principle Board (APB) as cited by Halim (2001) views accounting from the point of its function as "a service functions as a provider of quantitative information, particularly of a financial nature, about economic entity intended to be useful in making logic economic decisions and choices among various alternative courses of action. Accounting includes several branches, including financial accounting, management accounting and government accounting. From the aforementioned definition and explanation, it is known that:

1) The function (role) of accounting is to provide quantitative information on economic entities, particularly of a financial nature intended to be useful in economic decision-making, and in determining the choice among a set of available alternative actions.

2) The information generated by the accounting is intended to be useful as an input to be considered in a rational economic decision-making.

3) There are many branches of accounting.

4) Accounting as an "art" means that accounting includes a variety of techniques considered useful for certain fields. The Handbook of Accounting confirms that accounting can benefit following fields: financial reporting; tax planning and determination; independent audits; data processing and information systems; management and cost accounting; national income accounting; and management consulting. Furthermore, the above list has expanded to include new interesting developments, among others: international accounting, behavioral accounting, socio-economic accounting, government accounting, nonprofit accounting, accounting in developing countries. In fact, the existing researches and practices have brought accounting to the new limit, making accounting as a complete discipline.

\subsection{Previous Studies and Hypotesis Development}

The previous studies discussing the perceptions and interests, among others:

1) Latifah (2010), discussing the perception and expectation of the profession of psychologist. The research finding concludes that there is a considerable positive influence between perceptions and expectations on decision to choose the profession of psychologist. H1 : Perception gives positive influence on students' decision to choose accounting major.

2) Fatmasari (2011) in her study discusses the influence of students' perception 
on the interest in decision to choose the profession of Broker Dealer (WPPE) in the Capital Markets, concluding that there is significant influence of students' perceptions $\mathrm{H} 2$ : Interest gives positive influence on students' decision to choose accounting major. on the level of decision-making as WPPE.

\subsection{Research Gap}

This study examines the causes of the decline in interest and perceptions of prospective students to take accounting majors which later on nationally and macro impact on the number of accountants Indonesia is increasingly decreasing in number, thereby reducing the competitiveness in the market accounting services Indonesia. This is corroborated by the issue that says the accounting profession will be reduced and lost in the future replaced by machines and systems

The following is the theoretical framework in this study:

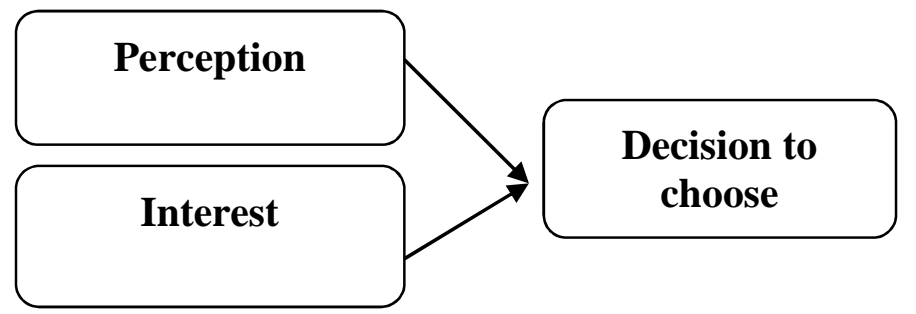

\section{RESEARCH METHODOLOGY}

\subsection{Population and sample}

The population in this study is Special Capital Region of Jakarta. The object of research is high school students who will continue their education to undergraduate level on Kebayoran Baru. Sample is a part of the overall population used by the author. The total sample for this study is 150 people, applying cluster sampling technique. The area for sampling is South Jakarta with high school students in the area as the respondents.

\subsection{Data Analysis Method}

1) Validity and Reliability.

2) Hypothesis testing is Coefficient of Determination $\left(R^{2}\right)$ Test, Simultaneous testing (F Test), Individual or Partial Test (T Test) and Multiple Linear Regression Analysis 


\subsection{Operational Variabel}

1) The Perceptual (independen variable, $X 1$ ) uses the theory proposed by Matlin in Novius (2008) that perception has two aspects, namely: pattern recognition and attention, The interest variable uses Crow and Crow in Gunarto (2007) that intere

2) The Interest (independen, $X 2$ ) variable uses Crow and Crow in Gunarto (2007) that interest consists of the factor inner urge, the factor of social motive, and the emotional factor (Emotional factor).

3) Interest (dependen variable, Y) using Kotler and Keller, (2012) consisting of Problem identification, Information search, Alternative evaluation, Decision and behavior after deciding

\section{RESULT AND DISCUSSION}

\subsection{Data Description}

1) Perception, with total data of 150 , the Minimum is 42.00 , the Maximum is 70.00, the Mean is 61.4067, the Standard Deviation is 3.97154, and the Variant is 15.773 .

2) Interest, with total data of 150 , the Minimum is 52.00 , the Maximum is 91.00 , the Mean is 82.3667, the Standard Deviation is 5.58451, and the Variant is 31.187.

3) Decision to choose, with total data of 150 , the Minimum is 40.00 , the Maximum is 85.00 , the Mean is 71.9067 , the Standard Deviation is 6.28020 , the Variant is 39.441.

\subsection{The Result of Reliability and Validity Test}

Based on the calculation of Cronbachs Alpha Based on Standardized Items from each of the aforementioned variables, it can be concluded that none of them is less than 0.60. It indicates that the construct is reliable. In this case, $n$ means the total of samples $=150-2=148$, with df 148 and alpha $=0.05$ obtained from $\mathrm{r}$ table $=$ 0.135 . The result of validity test of the variables perception and interest and decision to choose is shown in the table (attached). Based on the result of the test, it can be concluded that none of Corrected Item-Total Correlation is less than 0.135 . Thus, it shows for all questionnaire are valid.

\subsection{The Result of Regression Test}

Based on the table (attached), the regression equation is obtained as follows:

Y Decision to choose $=8242+0.804$ Perception +0374 Interest $+e$

Information:

$\mathrm{X} 1=$ The influence of perception

$\mathrm{X} 2=$ The influence of interest

$\mathrm{Y}=$ Decision to choose

$\mathrm{e} \quad=$ Error

The value of regression equation is interpreted as follows: 
1) Constant of 8.242 means that the Influence of Perception and Interest increases by 1 unit, it can be said that there is an increase of 8.242 in Decision to choose.

2) The regression coefficient of the Influence of perception is 0.804 means that if the Influence of perception increases by 1 unit, it will affect the Decision to choose for 0.804 unit.

3) The regression coefficient of the Influence of interest is 0.374 means that if the Influence of interest increases by 1 unit, it will affect the Decision to choose for 0.374 unit.

\subsection{The Result of Hypothesis Test}

\section{The Result of Partial Test (t Test)}

The result of statistical $t$ test with SPSS 19 as the medium is shown in the table (attached). It can be concluded that:

1) Variable $X 1$ (perception) has t count of 7.543 , bigger than t table of 1.655 with a significance value of 0.000 or greater than 0.05 (alpha $\alpha=5 \%$ ), so that the hypothesis one (H1) is accepted. It means that: the perception significantly influences the decision to choose. It shows that the magnitude of the decision to choose can be determined based on the influence of perception. The contribution of perception towards the decision to choose is $(0.804)^{2} \times 100 \%$ $=0.646 \%$

2) Variable $X 2$ (interest) has $t$ count of 4.927 , bigger than $t$ table of 1.655 with a significance value of 0.000 or greater than 0.05 (alpha $\alpha=5 \%$ ), so that the hypothesis two $(\mathrm{H} 2)$ is accepted. It means that: the interest significantly influences the decision to choose. It shows that the magnitude of the decision to choose can be determined based on the influence of interest. The contribution of interest towards the decision to choose is $(0.374)^{2} \times 100 \%=$ $0.139 \%$

\subsection{The Result of Determination Test}

The attached table of the test of coefficient of determination shows that the value of the coefficient of determination seen from the Adjusted R Square is 0.565. It means that $56.5 \% \mathrm{Y}$ can be explained by the second variation of independent variables, namely the perception and interest, while the remaining of $43.5 \%$ $(100 \%-56.5 \%)$ is explained by other causes outside the model or other variables that are not examined.

\subsection{Discussion}

\subsubsection{The influence of perception on the decision to choose accounting major}

Based on the results of data processing, there is a positive and significant influence of perception on the decision to choose accounting major in Jakarta. This is consistent with the finding of study conducted by Latifah (2010) that discusses perception, expectation, interest and decision to choose that there is a considerable positive influence of interest on the decision to choose. 
As described previously, perception is a process that involves prior insights in obtaining and interpreting a stimulus shown by senses like proposed by Matlin in Novius (2008).

\subsubsection{The influence of interest on the decision to choose accounting major}

Based on the results of data processing, there is a positive and significant influence of interest on the decision to choose accounting major in Jakarta. This is consistent with the finding of study conducted by Fatmasari (2011) that there is a considerable positive influence of interest on the decision to choose.

As described previously, interest is a tendency that causes a person to look for or try activities in a specific field. Interest is also interpreted as a positive attitude towards environmental aspects as proposed by Sandjaja (2006).

\section{CONCLUSION}

Research findings show that the perception partially influences the decision to choose accounting major positively and significantly. It can be concluded that the larger and higher and better the perception of a student in accounting major is, the greater the decision of the student to choose accounting major. Research findings show that the interest partially influences the decision to choose accounting major positively and significantly. It can be concluded that the larger and higher the interest of a student in accounting major is, the greater the decision of the student to choose accounting major.

To further improve the public interest to pursue education in accounting major, more approaches to the Indonesians about accounting should be taken earlier, followed by the urgency, benefit and function of accounting for daily life. It is expected that people know the importance of accounting in daily implementation. The perception of the difficulty of accounting can be slowly eliminated by the role of educational institutions in introducing accounting to public through education at early school age by entering accounting on the basic curriculum. Therefore, people will become familiar with accounting so that the lack of resources for accounting profession will be resolved. Furthermore, other researchers can use this study as a reference and develop other studies by using more variables and samples to increase accuracy in solving research problems. It is expected that this study will be able to help the problem of accounting major in society.

\subsection{Limitations}

This study is limited to the variables and samples used so that it needs to be added with a broader and representative sample generalization area in his research and the more powerful and comprehensive theory in solving the problem 


\section{REFERENCES}

Aiken, Lewis R. (1994). Psychological Testing and Assessment. MA: Allyn and Bacon.

Agung, Wahyu. (2010). Panduan SPSS 17.0 untuk Mengolah Penelitian Kuantitatif. Yogyakarta: Garailmu.

Accounting Principle Board (APB). (1971). Statement No. 04. Basic Concepts and Accounting Principles Underlying Financial Statement of Business Enterprise, Part 40.

Dajan, Anto. (1991). Pengantar Metode Statistik. Volume I. Jakarta: LP3ES..

Fatmasari, Ahad Dewi. (2011). The Influence of Student's Perceptions on the Interest of Profession As a Broker Dealer (WPPE) in Capital Markets. (Studi Pada Mahasiswa Fakultas Syar'iah Jurusan Ekonomi Islam IAIN Walisongo Semarang), skripsi mahasiswa IAIN Walisongo Semarang, 2011

Glass, G. V., \& Hopkins, K. D. (1970). Statistical Methods in Education and Psychology (pp. 501-509). Englewood Cliffs, NJ: Prentice-Hall.

Ghazali, Imam. (2006). Aplikasi Analisis Multivariate dengan Program SPSS $\left(4^{\text {th }}\right.$ Printing). Semarang: Badan Penerbit Universitas Diponegoro.

Kotler, Philip, et al. (2000). Manajemen Pemasaran Perspektif Asia. Yogyakarta: Person Education Asia.

Musgrave \& Musgrave. (1984). Public Finance in Theory and Practice. New York. McGraw-Hill Inc.

Latifah, Mutia. (2007). Persepsi dan Ekspektasi Mahasiswa Terhadap Profesi Psikologi. (Online). (2 Juni 2011)

Nasir, Mohammad. (1999). Metode Penelitian. Jakarta: Penerbit Ghalia Indonesia.

Nordiawan, Deddi \& Hertianti, Ayuningtyas. (2002). Akuntansi Sektor Public. Jakarta

Robbins, Stephen \& Judge, Timothy. (2009). Perilaku Organisasi (Organizational Behavior). Jakarta: Salemba Empat.

Stiggins, R. J. (1994). Student-involved Classroom Assessment ( $3^{\text {rd }}$ Edition). Ohio: Merill Prentice Hall.

Sugiyono. (2007). Metode Peneliian Bisnis (10 ${ }^{\text {th }}$ Printing). Bandung: CV Alfabeta.

Sekaran, Uma. (2006). Metodologi Penelitian Untuk Bisnis (Research Methods for Business ) (4 ${ }^{\text {th }}$ Edition). Jakarta: Salemba Empat.

Trihendradi. (2011). Analisis Statistik Menggunakan SPSS 19 Deskriptif Parametrik dan Non Parametrik, Yogyakarta: Penerbit Andi.

Sandjaja, S. Pengaruh Keterlibatan Orang Tua Terhadap Minat Membaca Anak Ditinjau dari Pendekatan Stres Lingkungan. Jakarta: UNIKA Atmajaya.

Sugiarto, et al. (1999). Pengantar Akuntansi I. Jakarta: Penerbit Universitas Terbuka.

Purwanto. (2010). Evaluasi Hasil Belajar. Yogyakarta: Pustaka Pelajar.

Walgito, Bimo. 2002. Pengantar Psikologi Umum. Yogyakarta: Andi Offset 